Historic, Archive Document

Do not assume content reflects current scientific knowledge, policies, or practices. 



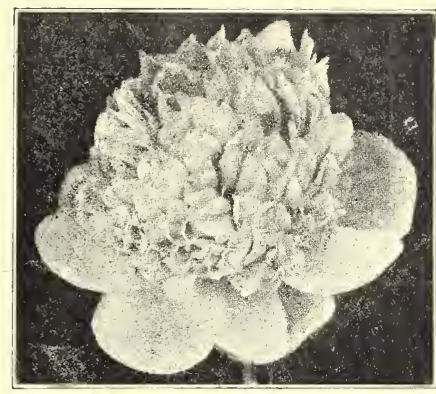

In our list of carefully selected Peonies, you will find the newer and finest varieties of Double Herbaceous Peonies. We have so simplified our "PEONY LIST" that it is very easy for anyone to make a choice selection, according to color, time of blooming or price. We are and have been studying hundreds of varieties and find our "PEONY LIST" covers the requirements of most Peony lovers.

The fact that we grow Peonies for the cut-flower market for so many years, has made us lay great stress on free-blooming sorts. We guarantee our Peonies to be true to name and will replace any blooming untrue to description.

\section{Time to Plant}

Peonies are best planted during the Fall season. September and October are ideal months for planting Peonies, but they may be moved anytime until the ground freezes.

\section{How to Plant}

Plant Peony roots in a good, medium rich, well drained black soil. Never permit fresh manure to come in contact with your Peony plants. Always use rotted manure sparingly.

Never plant your Peonies too deep. Too deep planting sometimes causes shy blooming. Plant so that about two inches of soil covers the eyes on the roots.

\section{Cultivation}

Peonies will respond to extra care. For best results they should be watered during their blooming period and again towards the end of summer. Cultivating and hoeing should continue throughout summer.

\section{BALMORAL GARDENS}

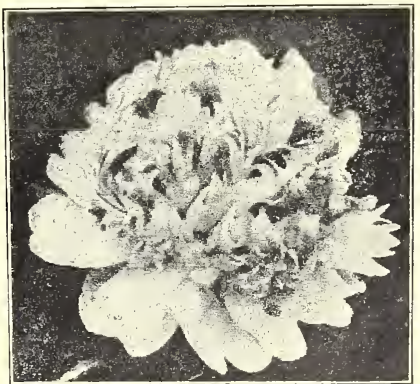



Our quality collections listed on the other side are excellent values at bargain prices.

All stock guaranteed true to name.

Our peonies are listed under separate colors and according to their blooming season.

Terms:-To new customers cash with order or payment before shipment is made or satisfactory reference.

\section{Early White}

9 Madame de Verneville (Crousse 1885), 30 inches. Large, very full bomb enclosed in a row of large pure white guard petals. our central carmine fecks with center blush when grod multi-

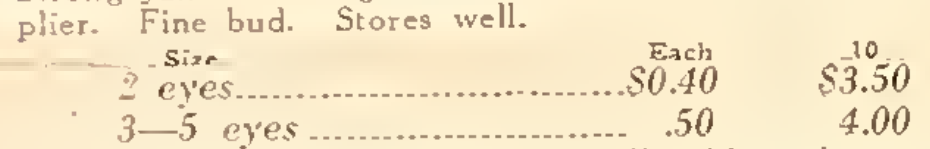

1 Duchesse de Nemours (Calot 1856), 33 inches. Cupshaped crown, sulphur white with greenish reflex when fully open. Clear

$$
2 \text { eyies. }
$$$$
3-5 \text { eyes }
$$

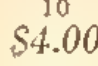

3 Festiva Maxima (Miellez 1851), 44 inches. Globular flower of rose type, combining enormous size with wondrous beauty, ofter
eight inches across. Pure paper white, flecked crimson. Rose eight inches across. Pure paper whitc, hecked crimson. Rosted the most popular white in existence.

Size

$3-5$ eres

$$
\begin{array}{rr}
\text { Each } & 10 \\
80.50 & \$ 4.00 \\
75 & 6.00
\end{array}
$$

Midseason White Avalanche (Crousse 1886) - - Large perfect shaped blooms, pure
white with creamy center, striped carmine. Extra fine. 2 Size $\begin{gathered}\text { Each } \\ 2 \text { eyes }\end{gathered}$ 3 -5 eyes $\quad .85 \quad 7.00$ Madame Emile Lemoine (Lemoine 1899), 30 inches. Immense
globular zcmi-rose type. Milk-white, very slightly tinged flesh pink covered with minute lilac dots finishing pure white. lific bloomer of typical blooms even on young plants. A vigorous $\begin{array}{rr}\text { Each } & 10 \\ \$ 1.25 & \$ 10.00 \\ 1.50 & 12.50\end{array}$

Late White

8.1 Couronne d'Or (Calot 1873). 34 inches. Extra large, flat semirose type. Has large petals, very compact blooms, is a splendid flecks having a ring of yellow stamens around the center, hence its name of "Crown of Cold." Our most dependable late whit cut flower. Very fragrant. $\quad$ Each
Size

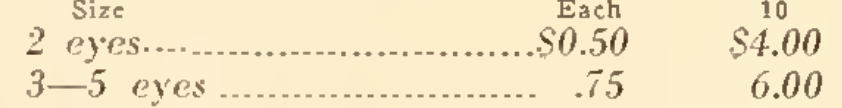

8.3 Monsieur Dupont (Calot 1872), 36 inches. Very large, flat, semi-rose type. lvory white center decidedly splashed with car-$$
2 \text { Size }
$$$$
\text { Each }
$$

$\$ 6.00$

3 -5 eyes

$.90 \quad 7.50$

9.0 Baroness Schroeder (Kelway 1890), 33 inches. Very large
globular rose type. Flesh white bud, bleaching to white when upen. Vigorous grower with strong stems. The most rose-lik in shape, appearance and fragrance of any white peony.

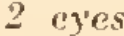

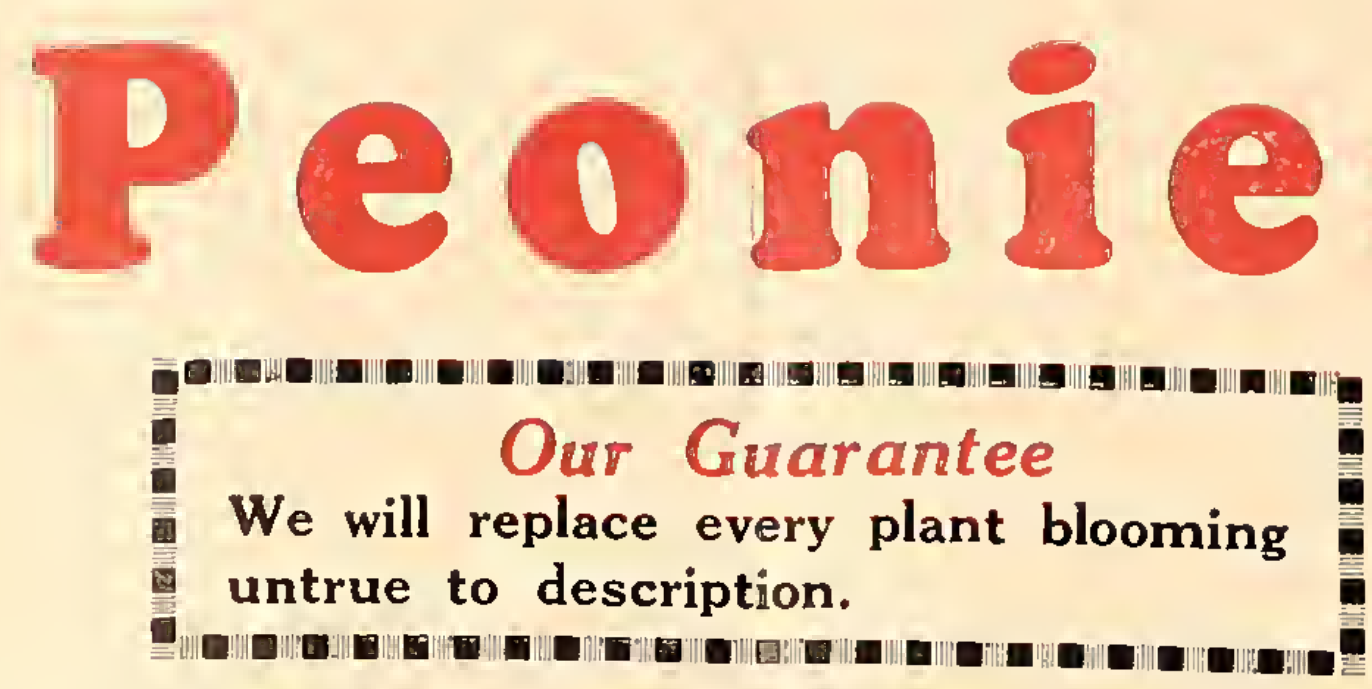

Early Light Pink

7.6 Delicatissima (Origin unknown) (Nearly identical with Floral Treasure.) Flesh, passing to blush white, full double, sweet scented; extra fine.

$$
\begin{aligned}
& \text { S eye } \\
& 2 \text { eyes...... } \\
& 3-5 \text { eyes }
\end{aligned}
$$

$\$ 3.50$

Octavie Demay (Calot 1867) 26 inches. Very large, flat crown Guard and center pale hydrangea pink, collar almost white. Strong stems. Very free. Dwarf habit but leaf stalk very low, admits cutting with long stem.

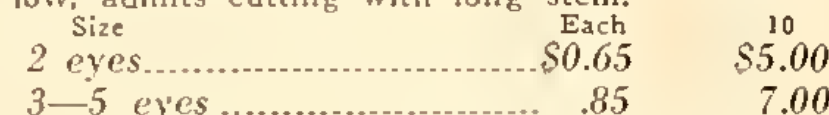

Midseason Light Pink

8.3 Venus (Kelway 1888), 38 inches. Large, compact crown, pale hydrangea pink, large petals with extra large guard-petals making
it the best pink bud for cutting. Rose fragrance. Erect and very

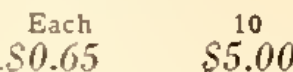

8.9

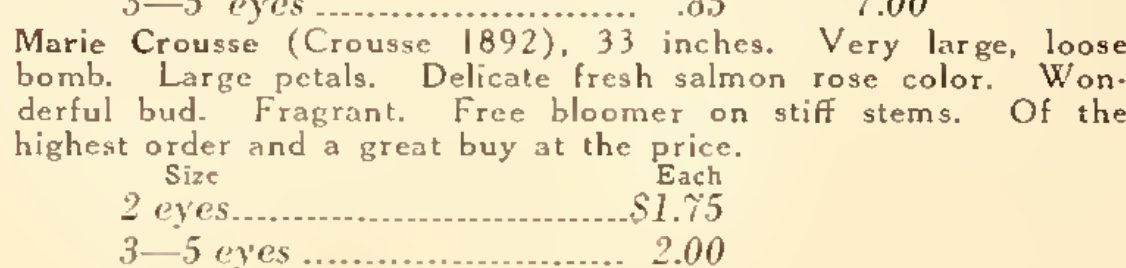

\section{Descriptions}

The figures preceding the name of varieties denote the rat ing given by the American Peony Society in 1921. The valuation was on a scale of ten, which represented perfection. The originator's name and the date when introduced are given in each description. The inches designate the height of the flower.

The American Peony Society has divided the types bloom in the following classes:

Single-A single row of broad guard petals with the ter filled with a mass of stamens.

Japanese-Same as the singles but the stamens and anthers are greatly enlarged into thick but narrow petal anthers.

Semi-Double-Having several rows of wide petals with center loosely intermixed with stamens and petals. Crown-Having wide petals in the center of the flower which form a high crown, encircled by narrow

hort petals.

Bomb-This type has all center petals of uniform width, forming a globe enclosed in a row of large guard petals.

Semi-rose-All petals are uniformly wide, interspersed with a few pollen-bearing stamens.

Rose-A perfect full rose shape, showing no stamens.

$$
2 \text { size }
$$

Early Dark Pink

7.1 Alexanderiana (Calot 1856) - Very large, Alight violet rose. Very fragrant. A st. Size
2 eyes

2 M. Jules Elie (Crousse (888) 32 inches. ull, high bomb of incurved chrysanthemu arge overlapping guard of wide petals. lossy lilac pink. Very full. Very fragran 2 eyes... $3-5$ eyes

Midseason Dark $\mathbb{P}$

7.8 Triomphe de L'Exposition de Lille (Calot well built flowers:
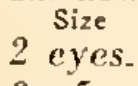
Each
$\$ 0.50$

3 Walter Faxon (Richardson 1907), 30 inche ar flower of uniform pure light salmon $P$ and highly

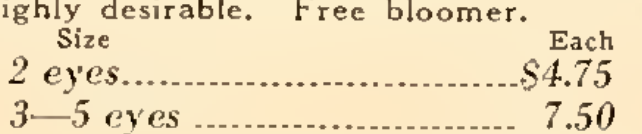

Late Dark Pink

8.7 Claire Dubois (Crousse 1886), 30 inches rose type. Clear deep violet rose. Delic
strong grower, free bloomer. For traveli lasting a great while when cut and still $d$ has no eoual.

$$
2 \text { Size }
$$

1.25 semi-rose type. Apple blossom Eew stamens. A recable fragrance. Stron with flowers in huge clusters. Very full. sort in every particular.

$$
2 \text { eyes }
$$

$3-5$ eye

Japanese Red

8.6 Mikado (World's. Fair 1893). 34 inches. Jap. Flower bright, all one shade of and golden tipped. Like a giant red pop durable. As marvelous in its way and stri peony. Size

2 Size

Packing Free and Transportation Charges Prepaid on all Orders of 5.00 or more. 


\section{Balmoral Gardens Quality Collections}

\section{Collection No. 1 \\ 5 Glorious Peonies, $\$ 2.85$ \\ $3-5$ eye roots}

Felix Crousse ...................... $\$ 0.75$

Madame de Verneville........... .50

Couronne D'Or....................... . .75

Delicatissima ......................... . .50

Tri d'Exposition DeLille......... . .75

Total

Special Price

$\$ 2.85$ prepaid

Collection No. 2

3 Fine Peonies, $\$ 1.35$ $3-5$ eye roots

Felix Crousse

Delicatissima $\$ 0.75$

Duchess De Nemours

Total.

Special Price

$\$ 1.35$ prepaid

Collection No. 3

Best Early and Late in Each Group, $\$ 5.75$

$3-5$ eye roots

Festiva Maxima.....................\$0.75

Couronne D'Or....................... .75

Octavie Demay...................... . .85

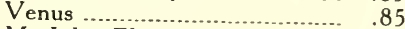

M. Jules Elie........................... 1.50

Claire Dubois ......................... 1.25

Felix Crousse .......................... .75

Delachie .................................... .75

Total

$\$ 7.45$

Special Price

$\$ 5.75$ prepaid

Collection No. 4

Prize Winning Group, \$2.95

Claire Dubois $\$ 1.25$

Festiva Maxima.

Karl Rosenfield.

Total

$\$ 3.50$

Special Price

$\$ 2.95$ prepaid

The above prices are net

BALMIORAL GARDENS

\section{HARDY PERENNIALS}

Strong, healthly plants that are guaranteed to satisfy. Try one of our SPECIAL OFFERS and have cut flowers this year out of your own garden.

Ea. Doz. Hd.

Achillea, The Pearl $\$ 0.20 \$ 2.00 \$ 15.00$

Aster, Novae, Angliae, Mixed.. $\quad 20 \quad 2.00 \quad 15.00$

Aquilegia, Mixed Hybrids

(Columbine)

$\begin{array}{lll}.20 & 2.00 & 15.00\end{array}$

Campanula, Canterbury Bells.. $.25 \quad 2.50 \quad 18.00$

Coreopsis lanceolate

$.20 \quad 2.00 \quad 15.00$

Dianthus Barbatus (Sweet William)

$.20 \quad 2.00 \quad 15.00$

Delphinium Gold Medal $\mathrm{Hy}$ brids

Gaillardia Grandiflora

$\begin{array}{lll}.20 & 2.00 \quad 15.00\end{array}$

Gypsophila (Baby Breath)....

$\begin{array}{lll}.20 & 2.00 \quad 18.00\end{array}$

Pyrethrum roseum Hybridum..

$\begin{array}{lll}.25 & 2.50 & 18.00\end{array}$

Phlox Elizabeth Campbell

$.35 \quad 3.50$

25.00

Phlox Mrs, Jenkins

$.20 \quad 2.00$

15.00

Salvia Azure Grandiflora.

$.20 \quad 2.00$

15.00

Veronica spicata

$.20 \quad 2.00 \quad 15.00$

SPECLAL OFFER NO. 1

14 plants ( 1 each of above)

$\$ 2.75$

SPECIAL OFFER NO. 2 42 plants ( 3 each of above)

$\$ 7.50$

SPECIAL OFFER NO. 3

70 plants ( 5 each of above) $\$ 12.00$

\section{Gladiolus Blubs Mixed, $\$ 3.00$ per Hundred}

The above prices are net Order Today

We Will Ship at Proper Time 